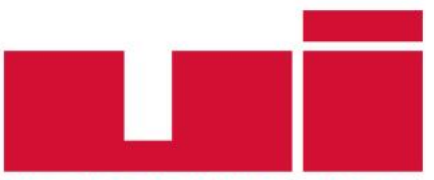

ULUSLARARASIILIȘKiLER

Akademik Dergi

Yayın ilkeleri, izinler ve abonelik hakkında ayrıntılı bilgi:

E-mail: bilgi@uidergisi.com.tr

Web: www.uidergisi.com.tr

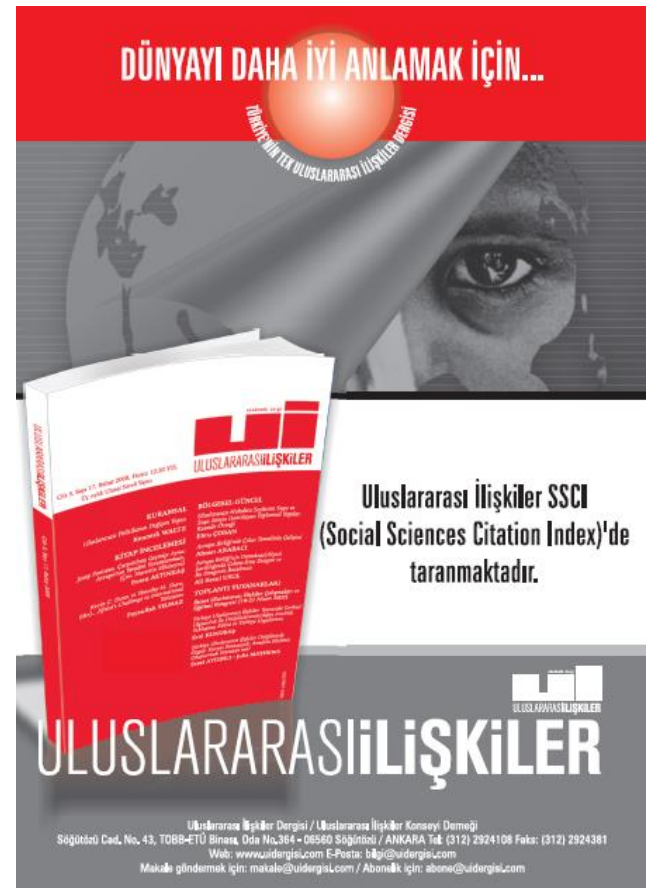

\title{
Köken Devlet ve Sinur-Aşan Sivil Toplum Politikaları: Türkiye Örneği
}

\section{Damla BAYRAKTAR AKSEL*}

* Dr., Doktora Sonrası Araştırmacı, Koç Üniversitesi

Bu makaleye atıf için: Bayraktar Aksel, Damla, "Köken Devlet ve Sınır-Aşan Sivil Toplum Politikaları: Türkiye Örneği", Uluslararası İlişkiler, Cilt 14, Sayı 56, 2017, s. 55-71.

Bu makalenin tüm hakları Uluslararası İlişkiler Konseyi Derneği'ne aittir. Önceden yazılı izin alınmadan hiç bir iletişim, kopyalama ya da yayın sistemi kullanılarak yeniden yayımlanamaz, çoğaltılamaz, dağıtılamaz, satılamaz veya herhangi bir şekilde kamunun ücretli/ücretsiz kullanımına sunulamaz. Akademik ve haber amaçlı kısa alıntılar bu kuralın dışındadır.

Aksi belirtilmediği sürece Uluslararası Illişkiler'de yayınlanan yazılarda belirtilen fikirler yalnızca yazarına/yazarlarına aittir. UİK Derneğini, editörleri ve diğer yazarları bağlamaz. 


\title{
Köken Devlet ve Sınır-Aşan Sivil Toplum Politikaları: Türkiye Örneği
}

\author{
Damla BAYRAKTAR AKSEL \\ Dr., Doktora Sonrası Araştırmacı, Koç Üniversitesi, İstanbul.E-mail: dabayraktar@ku.edu.tr
}

\begin{abstract}
ÖZET
Türkiye’den Avrupa'ya yönelik 1960'lardaki işçi göçünü takip eden dönemde yurtdışında ortaya çıkmaya başlayan ve özellikle 1980 darbesinin ardından siyasi göç hareketiyle ivme kazanan bir ulusaşırı sivil toplum hareketliliğinden söz etmek mümkündür. Son 20 yılda devletin yurtdışında yaşayan vatandaşlarına yönelik yaklaşımının değişimi ve yeni kurumsal yapılarla birlikte devlet-göçmen sivil toplumu ekseninde önemli farklılaşmalar yaşanmıştır. $\mathrm{Bu}$ çalışma, devlet ve göçmen toplulukların ulusaşırı alana dair uygulamalarının birbirini etkileyen süreçler olduğunu ortaya koyar. Türkiye'deki siyasi ortamdan etkilenen sivil toplum alanı; ideolojik, dini, siyasi ayrışmalar temelinde şekillenirken, son yıllarda devletin yurtdışında resmi olmayan lobi yaratma ve onu güçlendirme politikaları bu ayrışmaları derinleştirmektedir.
\end{abstract}

Anahtar Kelimeler: Göçmenler, Sivil Toplum, Yurtdışı Vatandaş Politikaları, Devlet-Toplum İlişkileri, Ulusaşırı Hareketler.

\section{Home State and Transnational Policies Toward Civil Society: The Case of Turkey}

\begin{abstract}
Turkish transnational civil society movement has started to emerge following the Gastarbeiter movement in the 1960s, and has accelerated following the 1980 coup and the political asylum mobility in its aftermath. Over the past two decades, there have been significant changes in the axis of state-emigrant civil society relations, particularly as a result of the state's changing approach to its citizens living abroad and the newly formulated institutional structures. This study reveals that the transnational practices of the state and emigrant communities are processes that affect each other. The divisions along the lines of ideological, religious and political membership within the civil society deepens with the governments' objective of creating and strengthening the informal lobby in the recent years.
\end{abstract}

Keywords: Emigrants, Civil Society, Emigrant Engagement Policies, State-Society Relations, Transnational Movements. 


\section{Giriş}

Küreselleşme çağında iletişim teknolojilerindeki ilerleme, hareketliliğin kolaylaşması ve ucuzlaması, uluslararası ve ulusal siyasi alanda etkin hale gelen ulusaşırı ağların ortaya çıkmasını hızlandırmaktadır. $\mathrm{Bu}$ süreçte, bir zamanlar ülkelerinden edilmiş kişiler olarak tanımlanan göçmenlerin ve onları takip eden yeni nesillerin, köken ülkelerindeki farklı aktörlerle çoklu ilişki ağları kullanarak sınırları aşan bir siyasallaşma içine girdiği görülmektedir. ${ }^{1} \mathrm{Bu}$ yeni ilişki biçimleri, parti politikalarından toplumsal hareketlere farklı yoğunluklar ve kurumsallaşma eğilimleri göstermekle birlikte, özellikle sivil toplum kuruluşları çevresinde şekillenmektedir. Ancak göçmenlerin artan etkinliği ve tanımlanmış devlet sınırları arasındaki esnekliği ulus-devletlerin iktidarını ortadan kaldırmamaktadır. Tersine, pek çok köken devlet sınırlar ötesindeki rolünü yeniden yaratarak geleneksel iktidar, ulus ve vatandaşlık anlayışlarını yeniden yapılandırmaktadır. ${ }^{2}$ Bu bağlamda, özellikle son 10 yılda köken devletlerin, yeni kurumsal ve resmi olmayan mekanizmalar aracılığıyla sınırlarının dışındaki üyeleri olarak tanımladıkları topluluklarla, "diasporik üyelik" üzerinden tanımlanan ${ }^{3}$ yeni ilişki biçimleri kurduğu görülmektedir.

Türkiye bağlamında bakıldığında, 1960’lardaki işçi göçünü takip eden dönemde yurtdışında ortaya çıkmaya başlayan ve özellikle 1980 darbesinin ardından siyasi göç hareketiyle ivme kazanan bir ulusaşırı sivil hareketlilikten söz etmek mümkündür. Çok farklı sosyo-ekonomik, etnik, dini, ideolojik örüntülerden oluşan bu sivil hareketlilik Türkiye'deki siyasi ve sosyal olaylar ve durumlardan etkilendiği kadar kendisi de ülkedeki süreçleri etkilemiştir. Bu hareketliliğin resmi-yarı resmi olarak kurumsallaştığı alan olarak yurtdışında yaşayan vatandaşlar ve vatandaşlığını bırakmış kişilerin kurdukları sivil toplum kuruluşlarının etkin bir rolü olduğu görülmektedir. Devletin yurtdışındaki bu kişilere yaklaşımına bakıldığında ise 1990'ların ikinci yarısıyla birlikte yeni kurumsal yapıların ortaya çıkmaya başladığı, ancak bu yeni yapılanma sürecinin özellikle 2000’lerden itibaren ekonomik, siyasal, sosyal ve kültürel planda yeni bir boyut kazandığı görülmektedir. Dışişleri Bakanlığı́nın 2017 rakamlarına göre yurtdışında, yaklaşık beş buçuk milyonu (büyük çoğunluğu Almanya olmak üzere) Batı Avrupa ülkelerinde, geri kalanı ise Kuzey Amerika, Orta Doğu ve Avustralya'da olmak üzere altı milyonu aşkın Türkiye kökenli bir nüfus bulunmaktadır. ${ }^{4}$ Bu nüfusla ilişkili olarak, Türkiye devlet kurumları tarafından tanınan, dolayısıyla sınırlı da olsa belli bir ilişki içerisinde olan 6500'den fazla sivil toplum kuruluşunun olduğu düşünüldügünde, Türkiye'yle bağlantılı önemli bir ulusaşırı sivil toplum alanının varlığından söz etmek yerinde olacaktır. ${ }^{5}$

Türkiye devletinin yurtdışındaki vatandaşlara dair yaklaşımı ve Yurtdışı Türkler ve Akraba Topluluklar Başkanlığı’nın da kurulması dolayısıyla ortaya çıkan kurumsal dönüşüm, literatürdeki yerini yavaş yavaş almaktadır. Yurtdışındaki Türkiye kökenli kişiler tarafından kurulan sivil toplum hareketleri hakkında vaka çalışmaları 2000'li yıllardan itibaren yaygınlaşmakla birlikte köken

1 Nina Glick Schiller et al., "From Immigrant to Transmigrant: Theorizing Transnational Migration", Anthropological Quarterly, Cilt 68, No.1, 1995, s.48-63.

2 Aihwa Ong, Flexible Citizenship: The Cultural Logics of Transnationality, Duke University Press, 1999; Peggy Levitt ve Rafael de la Dehesa, "Transnational Migration and the Redefinition of the State: Variations and Explanations", Ethnic and Racial Studies, Cilt 26, No.4, 2003, s.606.

3 Alan Gamlen, “The Emigration State And The Modern Geopolitical İmagination”, Political Geography, Cilt 27, No.8, 2008, s.840-856.

4 Türkiye Cumhuriyeti Dışişleri Bakanlığı, "Yurtdışında Yaşayan Türk Vatandaşları”, http://www.mfa.gov.tr/yurtdisindayasayan-turkler_tr.mfa, (Erişim Tarihi 13 Ekim 2017).

5 Veriler Çalışma ve Sosyal Güvenlik Bakanlığı (ÇSGB), Dış İlişkiler ve Yurtdışı İşçi Hizmetleri Genel Müdürlüğü websitesinden, ÇSGB raporlarından ve Amerika Türk Koalisyonu’nun (TCA) listesinden derlenmiştir. 
devletle olan ilişkilerine dair bütüncül bir bakış açısı henüz literatürde yerini almamıştır. Bu çalışma, bu alandaki boşluğu doldurmayı hedefleyerek, Türkiye devleti ile göçmenler (ve onları takip eden nesiller) tarafından kurulmuş sivil toplum alanı arasındaki ulusaşırı ağları ele almaktadır. Makalenin ilk bölümünde köken devlet literatürü üzerinde durulacak ve devletler ile göçmenler arasındaki ilişkiye dair bugüne kadar ortaya koyulmuş tezler, özellikle sivil toplum alanı bağlamında incelenecektir. Makalenin ikinci bölümü, 1960’lardan günümüze Türkiye devletinin yurtdışındaki vatandaşlarına dair politikalarını betimleyecektir. Son kısımda ise Türkiye kökenli kişilerin ulusaşırı pratiklerine dair dönüşümlerden ve bu dönüşümler bağlamında, Türkiye devlet politikalarının etkisinden bahsedecektir.

\section{Devletler ve Sınır-Aşan Sivil Toplum Politikaları}

Göçmenlerin (ve onları takip eden nesillerin) devletler ile olan ilişkileri göç literatüründe uzun yıllardır ele alınmış olsa da üzerinde durulan etkileşim, daha ziyade ikamet edilen ülkelerde yapısal ortamın tartışmaları çerçevesinde, sınırlı kalmıştır. Bununla birlikte, Avrupa ve Amerika Birleşik Devletleri'ndeki araştırmalarda sivil toplum alanına dair çalışmalarda ve köken ülkeyle olan ilişkilerin ele alınmasında farklılaşmanın yaşandığı görülmektedir. Çağlar’a göre, ${ }^{6}$ bu tür sivil toplum hareketlerine dair çalışmaların çoğu Orta ve Latin Amerika'dan ABD’ye giden göçmenleri ele almakta, buna karşılık Avrupa'daki göçmenlerin örgütlenmelerine dair görece daha az çalışma yayınlanmaktadır. Pek çok ülkeden göçü bünyesinde barındıran ABD'de göçmenlere dair yapılan çalışmalarda klasik asimilasyon modellerine karşı gelişen literatür, farklı göçmen gruplarının köken ülke ilişkilerine odaklanmaya yönelmiştir. Ulusaşırılık tartışmalarının ABD'den çıkmış olması da bu bağlamda şaşırtıcı değildir. Avrupa'da ise işgücü anlaşmaları dolayısıyla geçicilik üzerine kurgulanan söylemde, 1980’lerde kalıcılı̆̆ın kabulüne dönüşmeye başlasa da, göçmenlerin köken ülkeleriyle kurdukları ilişkilerin yakın zamana kadar entegrasyon açısından sorunlu olduğu kabulü hakimdir.

Göç alanında, son birkaç yıla kadar, köken devletler/milletler ve göçmenler arasındaki ilişkinin farklı yönlerini anlatan, ama ya rekabet halinde olan ya da birbirinden bağımsız olarak gelişen üç literatür bulunmaktaydı: Bunlardan ilki, 1970'lerden günümüze var olan klasik diaspora literatürü; ikincisi yine 1970'lerde ortaya çıkan ancak 1990'larda antropoloji ve kültürel çalışmalar alanıyla dönüşen ve zenginleşen ulusaşırılık (transnationalism) literatürü; ve son olarak 1980'lerin ortasından itibaren sınırlı olarak ortaya çıkan ve ilk başlarda kalkınma teorilerine içkin olarak gelişen köken devlet literatürü. ${ }^{8} \mathrm{Bu}$ üç literatür, köken devletler ile göçmenler arasında var olan ilişki ağını farklı boyutlarıyla ele almaktaydı. Diaspora ve ulusaşırılık kavramları, ortaya çıtıkları ilk dönemde, göçmenlerin "tahayyül edilmiş ulus/milletlere" doğru kurdukları ağlar ve sosyal alanlarla ilgilenmekteydi. Köken devlet literatürünün ana odağında ise neoklasik göç modellerine uygun olarak göçmen gönderen (çoğunluğu gelişmemiş veya gelişmekte olan) ülkelerin göç süreçlerinden edinebilecekleri, kalkınma süreçlerini hızlandırması beklenen ekonomik ve sosyal faydalar bulunmaktaydı. Köken devletlerin yurtdışındaki vatandaşlarına daha fazla ilgi göstermeye başlaması, çifte vatandaşlık gibi hakların genişletilmesi ve "diaspora" kelimesinin klasik literatürünün dışına çıkarak hem ulusaşırılık

6 Ayşe Çağlar, "Hometown Associations, The Rescaling Of State Spatiality And Migrant Grassroots Transnationalism”, Global Networks, Cilt6, No.1, 2006, s.3.

7 Ibid.

8 Alan Gamlen, “Diaspora Institutions And Diaspora Governance”, International Migration Review, Cilt 48, No.1, 2014, s.180-217; Michael Collyer, "Inside out? Directly Elected 'Special Representation'of Emigrants in National Legislatures and the Role of Popular Sovereignty”, Political Geography, Cilt 41, Temmuz, 2014, s.64-73. 
literatüründe hem de devlet söyleminde yerini almasıyla birlikte bu alanı anlamlandırmaya çalışan yeni yaklaşımların geliştiği görülmektedir.

Zira, diaspora literatürünün 1970'lerde ortaya çıkan öncelikli tartışması "mağdur olmuş diasporalar" kavramı üzerinden ve genellikle başka gruplar veya inançlar arasında azınlık olarak yaşayan toplulukları tanımlamak üzerine şekillenmiştir. ${ }^{9}$ Ancak Brubaker ${ }^{10}$ ve Waldinger' in ${ }^{11}$ de belirttiği üzere günümüzde artık diaspora kelimesi neredeyse göçmen kelimesiyle dönüşümlü olarak kullanılmaktadır. Waldinger, devletler ve göçmenler tarafından diaspora kelimesine atfedilen yeni anlamlandırmaların, tanımlayıcı bir süreç olmanın ötesinde stratejik bir süreç olduğunun altını çizer. ${ }^{12}$ Diaspora kelimesi, köken devletlerin göçmenlerle (ve onları takip eden nesillerle) olan ilişkilerinin "aidiyet ve sadakat" gibi kavramlar etrafında yeniden şekillendirilmesinde kavramsal bir boşluğu doldurmakta ve böylece yeniden tanımlanmaktadır. Ancak klasik diaspora literatürü ve söyleminde geri dönüş mitinin altı çizilirken, köken devletler tarafından günümüzde kullanılan diaspora stratejileri göçmenlerin geri dönüşlerini hedeflememekte, bu kişilerin bulundukları yerden anayurtları için makbul ulusaşırı üyeler olmaları beklenmektedir.

Meseleyi devletlere odaklanarak ele alan yeni "göç veren devlet” literatürüne göre, göç süreçleri artık salt ekonomik kalkınma odaklı değil sosyal, siyasi ve kültürel boyutlarıyla birlikte ele alınmaktadır. Kurulmaya çalışılan ilişki ağının pekişmesinde yurtdışından seçimlere katılım gibi genişleyen vatandaşlık hakları önemli bir rol oynar. ${ }^{13}$ Göçmenler (ve sonraki nesiller) bağlamında ise kurulmaya çalışılan yeni ilişki biçimleri, bir yandan ikamet edilen ülkede edinilen sermayenin köken ülkeye yönelik kullanılabilmesini kolaylaştırırken, diğer yandan genişleyen vatandaşlık haklarından faydalanabilmeyi mümkün kılar. Ancak, Kuzey Afrika ve Orta Doğu ülkelerinin yurtdışındaki vatandaşlarıyla olan ilişkilerini ele alan Brand'ın da öne sürdüğ̈ gibi, vatandaşlık ve başka haklar konusunda de jure genişleme yaygınlaşsa bile, pek çok otoriter rejim tarafından bu durum meşruiyet sağlamak ve yurtdışındaki toplulukları daha yakından gözetlemek amacıyla kullanılmaktadır. ${ }^{14}$

Sivil toplum hareketlerinin ulusaşırılık tartışmalarında 1990’lardan bu yana merkezi bir rolü olmuştur. Zira sivil toplum kurumları kolektif pratikleri içermeleri nedeniyle göçmen olsun olmasın farklı toplulukların fiziksel sınırların ötesindeki faaliyetlerini ele almayı mümkün kılmaktadır. Bu yaklaşım, özellikle ulusaşırıllı̆ın iktidar odaklarına karşı “özgürleştirici” olduğu ve kozmopolitan toplumlar yarattığı argümanını savunan erken dönem küreselleşme ve ulusaşırılık teorisyenleri tarafından sahiplenilmiştir. ${ }^{15}$ Karşıt argümanlara göre göçmenler tarafından yaratılan alan, küreselleşme süreçlerinin sonunda yaratılacağına inanılan "ulusaşırı sivil toplumun” aksine, çoğu zaman ulus, milliyet, din ve kimlik gibi farklı aidiyetler üzerinden kurulmakta ve bu aidiyetler üzerinden dışarı kapalı yeni alanlar yaratmaktaydı. ${ }^{16}$ Belki de bu tartışmanın etkisiyle, göç kökenli grupları ele alan

9 Stephane Dufoix, Diasporas, Berkeley, University of California Press, 2008, s.1.

10 Roger Brubaker, “The 'Diaspora' Diaspora”, Ethnic and Racial Studies, Cilt 28, No.1, 2005, s.1-19.

11 Roger.Waldinger, “Foreword”, Stephane Dufoix (der.), Diasporas, Londra, University of California Press, 2008, s.xi.

12 Ibid., xii.

13 Collyer, "Inside out?".

14 Laurie Brand, "Arab Uprisings And The Changing Frontiers Of Transnational Citizenship: Voting From Abroad in Political Transitions", Political Geography, Cilt 41, Temmuz 2014, s.54-63.

15 Arjun Appadurai, "Disjuncture And Difference in The Global Cultural Economy”, Cultural Theory: An Anthology, 1990, s.282-295; Homi Bhabha, Nation and Narration, Psychology Press, 1990.

16 Roger Waldinger ve David Fitzgerald, “Transnationalism in Question”, American Journal of Sociology, Cilt 109, No.5, 2004, s.1177-1195. 
ulusaşırılık tartışmalarında, "sivil toplum” yerine göçmenliği ön plana çıkaran "göçmen dernekleri/ kurumları" kavramları tercih edilmektedir. Bununla birlikte, Collyer'in de belirttiği gibi göçmenlere ait sivil toplum kurumlarını ele alan çalışmalar, çoğunlukla göçmenlerin sürgünlük hallerine hitaben devlet karşıtllğı üzerinden şekillenen bir ilişkiden bahsetmektedir. ${ }^{17}$

Türkiye'deki devlet-göçmen ilişkileri ve ulusaşırı sivil toplum tartışmalarına bakıldığında, 1970'larda bir dönem yeşeren ancak 2000'lere kadar sınırlı kalan bir literatürün varlığından söz edebiliriz. Göç süreçlerini takip eden erken dönemde Abadan-Unat ${ }^{18}$ ve Penninx ${ }^{19}$ çalışmalarıyla başlayan kalkınma-odaklı yaklaşımda Türkiye devletinin işçi gönderen ülke konumu üzerinde durulmaktadır. Bu yaklaşıma paralel olarak şekillenen literatür, konuyu bir yandan göçmen dövizleri üzerinden göçün ekonomik boyutunu ele alarak değerlendirirken, diğer yandan da demografi üzerinden tartışmaktadır. ${ }^{20}$ Schmitter Heisler'in ${ }^{21}$ ve Sayarı'nın ${ }^{22}$ çalışmaları ise Türkiye devletinin göçmen ve yurtdışı vatandaş politikalarını, meselenin ekonomik boyutunun ötesinde analiz etmektedir. Göçmenler ile Türkiye devleti arasındaki ilişkiye dair tartışmaların yeniden alevlenmesi 2000'li yılları bulmaktadır. Bu dönemki erken analizler, başta Almanya olmak üzere farklı ülkelerdeki göçmenlerin Türkiye'ye yönelik pratiklerini incelerken, devletten yola çıkan kalkınma odaklı tartışmaların aksine, meselenin köken devlet boyutuna değinmektedir. ${ }^{23}$ Sonraki 10 yıl boyunca yayınlanan araştırmalarda iki dönüşüm görülmektedir. Bunlardan ilki, çalışmaların coğrafi odağının Batı Avrupa'dan farklı ülkelere doğru genişlemesidir. İkinci dönüşüm ise devlet-sivil toplum ilişkilerinde "çatışma" dışındaki ilişki biçimlerinin de gündeme gelmeye başlamasıdır. Geçmişteki tartışmalar, göçmenlerin hem Türkiye'de hem de başka ülkelerdeki Türkiye kökenli etnik, dini gruplar, partiler ve toplumsal hareketler ile kurduğu ağlara odaklanmaktadır. İkinci dönüşüm açısından literatürde ele alınan grupların çeşitlenmesi kadar devlet-sivil toplum diyaloğuna dair politika değişikliği sonucunda yeni ağların ve alanların oluşması da etkili olmuştur.

$\mathrm{Bu}$ bölümde göçmen gönderen, köken devletlerin yurtdışındaki vatandaşlarına yönelik politikalarına dair var olan literatür ele alınmıştır. Gamlen'ın da ifade ettiği gibi, ortaya çıkan diaspora literatürü iki aidiyet ve çifte vatandaşlık gibi olgulara ve bunlara bağlı olarak gelişen ulusaşırı devletvatandaşlık ilişkisine, artık engellenmesi gereken bir sorun olarak yaklaşmamaktadır. ${ }^{24}$ Türkiye'nin ulusaşırı üyelik politikalarında, özellikle 1990’lardan itibaren yaşanan dönüşümler içerisinde, göçmenlere yönelik yaklaşım değişikliği göze çarpmaktadır. Bir sonraki bölümde tarihsel süreç içerisinde ulusaşırı vatandaş ve sivil toplum politikalarına yönelik idari ve yasal dönüşümler ele alınacaktır.

17 Michael Collyer, “Transnational Political Participation Of Algerians in France. Extra-Territorial Civil Society Versus Transnational Governmentality”, Political Geography, Cilt 25, No.7, 2006, s.836-849.

18 Nermin Abadan-Unat, Turkish Workers in Europe 1960-1975: A Socio-Economic Reappraisal, Brill, 1976.

19 Rinus Penninx, "A critical review of theory and practice: the case of Turkey”, International Migration Review, 1982, s.781-818.

20 Ahmet Akgündüz, "Migration to and from Turkey, 1783-1960: Types, numbers and ethno-religious dimensions", Journal of Ethnic and Migration Studies, Cilt 24, No.1, 1998, s.97-120; Ali S. Gitmez, Yurtdışına İş̧̧i Göçü ve Geri Dönü̧̧ler: Beklentiler, Gerçekleşenler, Alan Yayıncılık, 1983.

21 Barbara Schmitter-Heisler, "Sending Countries And The Politics Of Emigration And Destination", International Migration Review, Cilt 19, No.3, 1985, s.469-484.

22 Sabri Sayarı, "Migration Policies Of Sending Countries: Perspectives On The Turkish Experience", The Annals of the American Academy of Political and Social Science, 1986, s.87-97.

23 Betigul E. Argun, Turkey in Germany: The Transnational Sphere of Deutschkei, Routledge, 2003; Eva Østergaard-Nielsen, Transnational Politics: The Case Of Turks And Kurds in Germany, Routledge, 2003.

24 Gamlen, "The Emigration State And The Modern Geopolitical Imagination". 


\section{Türkiye Devleti'nin Yurtdışı Vatandaş ve Sivil Toplum Politikaları}

Erken cumhuriyet döneminde ülke içinden yurtdışına yönelik yoğun bir hareketlilik yaşanmış olsa $\mathrm{da}$, giden kitlelerin çoğunluğunun devletin vatandaşlık tanımı dışına çıkmış/çıkartılmış olması dolayısıyla 1960’lara kadar önemli bir yurtdışı vatandaş politikasından söz etmek mümkün değildir. 1960’lardaki yoğun işçi hareketliliğiyle birlikte sık sık Meclis’in gündemine gelen yurtdışına göç konusunun, salt ekonomik boyutun ötesine geçerek, sosyal ve siyasi alana genişlemeye başlaması ancak 1970'lerin sonunu bulmuştur. Bu dönem, işçi göçü anlaşmalarının sona erdirilmesine rağmen, özellikle kıta Avrupa'sında yaşayan Türkiye kökenli vatandaşların, nüfuslarının artmaya başlaması ve bununla ilişkili olarak sivil toplum kuruluşları etrafında yaygın olarak örgütlenmeye başlaması açısından önem taşır. 1980'lerin artan kimlik siyaseti ve darbe sonrası mülteciler tarafından şekillenen sivil toplum ortamında devletin verdiği ilk yanıt, Østergaard-Nielsen'in de ifade ettiği üzere tepkisel politikalar etrafında şekillenmiştir. ${ }^{25}$ 2000'lerin başından itibaren, 2010'da kurulan Yurtdışı Türkler ve Akraba Topluluklar Başkanlığı'nın da etkisiyle, hem ulusaşırı vatandaşlık hem de ulusaşırı sivil toplum politikaları bağlamında yeni ve proaktif bir yaklaşımın izlenmeye başlandığı görülmektedir.

1961 yılında Almanya’yla yapılan ikili işgücü anlaşması, Türkiye’nin yurtdışı politikasının geçmişi açısından bir dönüm noktası olarak kabul edilmektedir. ${ }^{26}$ Bu tarihe kadar Türk vatandaşlı̆̆ını koruyan bireylerin hareketliliği nicel olarak oldukça sınırlı kalmışken, 1960’larda başlayan süreçle birlikte "toplu göç" kavramı literatürde yerini almaya başlamıştır. Erken dönem devlet politikaları, yurtdışında yaşayan vatandaşlara dair başlıca iki öngörü üzerine kurulu bir anlayışla oluşturulmuştur: geçicilik ve işçilik. Bu anlayışa göre yurtdışına gidecek olan göçmenler kısa süreli ve sadece çalışmak amacıyla yurtdışında bulunacaklardı. Sayarı́ya göre Türkiye'nin işgücü anlaşmalarını imzalamasında başlıca iki politika endişesi ön plana çıkmıştır: ülkedeki işgücü piyasasında var olan baskının azaltılması ve Türk ekonomisini etkileyen yabancı döviz krizleriyle başa çımma. ${ }^{27} \mathrm{Bu}$ dönemde devlet kurumlarıyla göçmenler arasında yurtdışında kurulan iletişim, bireyler üzerinden, başta konsolosluk çatısı altında görev yapan ataşeler aracılığıyla gerçekleşmekteydi. Ön plana çıkan konular sosyal güvenlik sorunları, gündelik meseleler ve geride bırakılan aile bireylerine gönderilecek dövizlerin idaresi gibi konuları içermekteydi. ${ }^{28}$

Yurtdışında işçi hareketliliği çerçevesinde göç etmiş kişilerin kalıcılığının anlaşılması 1970'lerin sonunu ve 1980 'leri bulmuştur. Geçicilikten kalıcılığa yönelik yaklaşım değişikliği, düzenlenecek politikaların belirlenmesi açısından belirleyici olmuştur. İkamet edilen ülkenin vatandaşlı̆ını edinme konusunda teşvikler başlamış olsa da vurgu, "yeni vatandaşlığa rağmen Türk kültür ve değerlerinin korunması” çerçevesinde şekillendirilmiştir. 1982 Anayasası’nın 62. maddesi sosyal güvenlik hakları altında "yabancı ülkelerde çalışan Türk vatandaşları" başlı̆̆ını taşımaktadır:

Devlet, yabancı ülkelerde çalışan Türk vatandaşlarının aile birliğinin, çocuklarının eğitiminin, kültürel ihtiyaçlarının ve sosyal güvenliklerinin sağlanması, anavatanla bağlarının korunması ve yurda dönüşlerinde yardımcı olunması için gereken tedbirleri alır. ${ }^{29}$

Anayasa, yurtdışında yaşayan Türk vatandaşlarının başta sosyal güvenlik ve kültürel haklar olmak üzere çeşitli meselelere dair ihtiyaçlarına dair tedbirler alınmasının altını çizerken, bu dönemde

25 Østergaard-Nielsen, Transnational Politics.

26 Abadan-Unat, Turkish Workers in Europe 1960-1975.

27 Sayarı, "Migration Policies Of Sending Countries", s.91.

28 Can Ünver, Otuzbeş Yıllık Göçve Bürokrasi Tanıklıklarım, Ankara, Phoenix Yayınları, 2008, s.20.

29 Türkiye Büyük Millet Meclisi, “Türkiye Cumhuriyeti Anayasası”, https://www.tbmm.gov.tr/anayasa/anayasa82.htm (Erişim Tarihi 13 Ekim 2017). 
bir yandan da günümüzde halen kullanılan "yurtdışındaki makbul vatandaş" tanımı da yaratılmıştır. $\mathrm{Bu}$ tanıma göre, "anarşist ve terörist" olarak tanımlanan bir grup, vatandaşlık bağı bulunsun ya da bulunmasın, devletle olan ilişki alanının dışında bırakılmıştır. Çoğunluğu mülteci olan bu grup içerisinde Türkiye aleyhinde "yanlı ve maksatlı propaganda yapanlar” bulunmakta ve bu kişiler Türk devleti açısından bir sorun teşkil etmektedir. ${ }^{30}$ Makbul vatandaşlara yönelik olarak yeni aidiyetlerine rağmen vatandaşlıklarının korunmasını öngören bir yaklaşım tercih edilmiştir. Bu yaklaşımın bir sonucu olarak, 1981 yılında kabul edilen yasa değişikliğiyle, devlete bildirilmesi koşuluyla çifte vatandaşlik uygulamasına geçilmiştir. ${ }^{31}$

Ayrıca bu dönem, başta Avrupa ülkeleri olmak üzere, vatandaşların yaşadığı ülkelerde sivil toplum hareketlerinin yeşerdiği dönemdir. Farklı ülkelerdeki sivil toplum süreçlerini ele alan ileriki bölümlerde de anlatılacağı üzere, sivil toplum hareketliliğini körükleyen önemli etkenler; Türkiye’deki siyasi kutuplaşma, 1980 darbesi sonrasında oluşan mülteci göçü ve Avrupa'da güçlenen siyasal İslam'dır. Bu dinamik siyasi ortamda, Türkiye’ye yönelik aidiyetin güçlendirilmesi için kültür-odaklı bir politika üzerinden hareket edildiği görülmektedir. 1980 ve 1990’lı yıllarda Diyanet İşleri Başkanlığı’nın yurtdışındaki etkinliği arttırılmış, genellikle başkanları bulundukları ülkedeki Türkiye’nin gönderdiği din müşavirleri olması nedeniyle devletle organik bağı olan Diyanet İşleri Türk İslam Birliği (DİTİB) gibi dernek ve federasyonların altında cami dernekleri oluşmaya başlamıştır. Devletin dini alan üzerindeki egemenliğini pekiştirme çabaları sonucunda Milli Görüş gibi büyük örgütlerden devlet İslam'ına ait kurumlara yönelik kaymalar olduğu göze çarpmaktadır. Yabancı ülkelerle sivil toplum diyaloğunu oldukça sınırlandıran 1983 tarihli ve 2908 sayılı eski Dernekler Kanunu’nun belirlediği çerçevede, sivil toplum ile konsolosluklar üzerinden irtibat kurulması ve bildirim yapılması yaklaşımı esas alınmıştır:

Yurt dışında Türk vatandaşları tarafından kurulacak derneklerin tüzüklerinin tasdikli iki nüshasının ve yönetim kurulu ile dernek üyelerinin kimliklerini gösterir bir listenin, İçişleri Bakanlı̆̆ına gönderilmek üzere, derneğin bulunduğu yerdeki yoksa en yakındaki Türk konsolosluğuna bir ay içinde verilmesi zorunludur. Bu dernekler, yönetim kurulunda vuku bulacak değişiklikleri ve yeni girecek üyelerin kimliklerini de aynı usule göre bildirirler. Türk vatandaşları tarafından yurt dışında, bu Kanunla yasaklanmış amaçlarla dernek kurulamaz ve Türk vatandaşları bu türden derneklere üye olmazlar. ${ }^{32}$

Yurtdışında kurulmuş olan derneklerin Türkiye'deki devlet kurumları tarafından tanınabilmesi için kuruluşlarından sonra belli bir süre içerisinde konsolosluklar üzerinden dernek bilgilerinin devlet kurumlarına verilmesi uygulaması halen devam etmektedir. İçişleri Bakanlığı’na bağlı Dernekler Daire Başkanlığı’nın derneklerin idaresine dair 2002 yönetmeliğine göre Türk vatandaşları tarafından yurtdışında kurulan ve İçişleri Bakanlığına gönderilen dernek tüzükleri ile, yönetici ve üye kimlikleri hakkındaki bilgilerin takibi, derneklerin ilgili birimlerle koordinasyonu, kanunla yasaklanmış amaçlarla kurulan derneklere üye olan vatandaşlarla ilgili işlemlerin yapılması konusunda Dış İlişkiler Şube Müdürlügü sorumlu tutulmuştur. ${ }^{33}$

1980'lerden beri tercih edilen bir başka uygulama da dağınık yapıdaki derneklerin çatı kuruluşlar altında bir araya getirilmesidir. 2000 yılında yurtdışında kurulmuş olan sivil toplum

30 Kenan Evren, Kenan Evren'in Anıları. 1. Cilt, İstanbul, Milliyet Yayınları, 1991.

31 Fuat Keyman ve Ahmet İçduygu, "Globalization, Civil Society And Citizenship in Turkey: Actors, Boundaries And Discourses”, Citizenship Studies, Cilt 7, No.2, 2003, s.219-234.

32 Bkz. Türkiye Büyük Millet Meclisi, “Türkiye Cumhuriyeti Anayasası”, Madde 72, https://www.tbmm.gov.tr/anayasa/ anayasa82.htm (Erişim Tarihi 13 Ekim 2017).

33 Bkz.http://www.dernekler.gov.tr/tr/Mevzuat/meri-yonetmelikler/KGcD-Usul-Esaslarina-Dair-Yonetmelik.aspx. 
kuruluşlarının geliştirilmesi için temsilcilikler tarafından yapılan çalışmalara dair Meclis'te verilen bir soru önergesine dönemin Dışişleri Bakanı İsmail Cem şu şekilde cevap vermektedir:

Yurtdışında yaşayan vatandaşlarımız tarafından kurulan derneklerin sayısı bir hayli fazladır. $\mathrm{Bu}$ dağınıklı̆ğı gidermek üzere 1980 yılından itibaren, derneklerin ciddi sivil toplum kuruluşlarına dönüşmelerini sağlamak için çatı örgütleri altında toplanmaları teşvik edilmiştir. Bu çerçevede 1986 yılından itibaren kapsamlı bir çatı örgütü niteliğinde olan Avrupa'da Türk Dernekleri Koordinasyon Kurulları oluşturulmuştur. ABD ve Kanada'da Türk Dernekleri Federasyonu ve Asamblesi, Avustralya'da ise Türk Dernekleri Konseyleri teşkil edilmiştir. Bu yapılırken çatı örgütlerinin birleştirici özelliklerinin olmasına, Cumhuriyeti kuran değerlere ve ülke bütünlüğüne saygılı hiçbir dernek ve kuruluşu dışlamamaya özen gösterilmektedir. ${ }^{34}$

Türkiye devletinin yurtdışındaki vatandaşlara yönelik yaklaşımı 1990'ların ikinci yarısıyla birlikte yeni bir yapılanma içine girmiştir. 1996'da yayınlanan yurtdışındaki vatandaşlara dair Meclis Araştırma Komisyonu raporunun, konsolosluklarla Türk vatandaşları arasında "mesafe" olduğu değerlendirmesi dikkate alınarak 1998'de yurtdışındaki vatandaşları temsil etmek üzere devlet bakanlığı altında bir danışma kurulu kurulmuştur. ${ }^{35}$ Ancak bu kurul, hem yurtdışındaki sivil toplum kuruluşlarınca kendilerini temsil etmediği eleştirileri çerçevesinde tepki alır hem de bir kaç toplantı dışında etkili olamaz. 2003'te yayınlanan TBMM Araştırma Komisyonu raporunda, yurtdışındaki vatandaşların bulundukları ülkelerde vatandaşlığa geçmeleri ve politik alanda yer almaları durumunda daha çok hak elde edeceklerinin altı çizilmiş ve yurtdışındaki vatandaşlarla ilgili strateji çerçevesinde bir takım ana ilkeler belirlenmiştir ${ }^{36}$. Bu ilkeler çerçevesinde gelecek kuşakların kültürel kimliklerinin ve Türkiye ile bağlarının korunması ve geliştirilmesi, bulundukları ülkelerle Türkiye arasında “iyi ilişkilerin ve dostluğun köprüsü” olmaları hedeflenmektedir. Araştırma Komisyonu raporu, hangi ülkede yaşadığına bakılmaksızın, "Türkiye Cumhuriyeti’ne vatandaşlık bağı ile bağlı, teröre karışmamış” her bir bireyin Türk devleti için ulaşılması gereken bir hedef olduğunu belirterek, devletin iletişimini sürdüreceği kitleyi tanımlamıştır. Raporda sivil toplum örgütlerine dair yapılan atıf, önceki döneme göre farklı bir yaklaşıma gidildiğini ortaya koyar:

Kurulacak olan bu birim vatandaşlarımızın karşılaşıtıları sorunların çözümünde yardımcı olmalı, AB Hukuku ve Uluslararası Hukuktan doğan haklarını izlemeli ve çözüm yolları aramalı, ayrıca vatandaşlarımızın ekonomik, siyasi ve diğer potansiyellerinin ülkemiz yararına değerlendirilmesi konusunda etkin çalışmalarda bulunmalıdır. Bu birim yapacağı çalışmalarda, $A B$ vatandaşlığı ve sonucunda yurtdışında etkin bir Türk lobisinin oluşturulması amacıyla bu konuda faaliyetlerde bulunan sivil toplum örgütleri ile de gerekli koordinasyonu sağlamalıdır. ${ }^{37}$

Araştırma raporunun sonuçları, devletin sonraki on yılda geliştireceği politikayı anlamlandırmak açısından önemlidir. Raporda belirtilen hususlara uygun biçimde, ilk olarak 2004'ten itibaren Dışişleri Bakanlığı’na bağlı misyonların koordinasyonunda, geçmişe göre daha geniş katılımlı, sivil toplum

34 Türkiye Büyük Millet Meclisi, “Erzincan Milletvekili Tevhit Karakaya tarafından Dışişleri Bakanı Sayın İsmail Cem’e Yöneltilen Yazılı Soru Önergesinin Cevabı”, http://www2.tbmm.gov.tr/d21/7/7-1373c.pdf (Erişim Tarihi 13 Ekim 2017).

35 Østergaard-Nielsen, Transnational Politics, s.110.

36 Türkiye Büyük Millet Meclisi, “İstanbul Milletvekili Ali Rıza Gülçiçek ve 20 Milletvekili ile Ordu Milletvekili Eyüp Fatsa ve 26 Milletvekilinin; Yurtdışında Yaşayan Vatandaşlarımızın Sorunlarının Araştırılarak Alınması Gereken Önlemlerin Belirlenmesi Amacıyla Anayasanın 98 inci, İçtüzüğün 104 ve 105 inci Maddeleri Uyarınca Birer Meclis Araştırması Açılmasına İlişkin Önergeleri ve (10/8,48) Esas Numaralı Meclis Araştırma Komisyonu Raporu” https://www.tbmm. gov.tr/sirasayi/donem22/yil01/ss335m.htm (Erişim Tarihi 13 Ekim 2017).

37 Türkiye Büyük Millet Meclisi, “İstanbul Milletvekili Ali Rıza Gülçiçek ve 20 Milletvekili” https://www.tbmm.gov.tr/ sirasayi/donem22/yil01/ss335m.htm (Erişim Tarihi 13 Ekim 2017). 
toplantıları gerçekleştirilmeye başlanmıştır. 2004, Türkiye'nin AB adaylık sürecinde sivil toplum gelişimi, devlet-sivil toplum ilişkileri ve yurtdışındaki kuruluşlarla çalışmalara dair alanı genişleten 5253 sayılı Dernekler Kanunu’nun düzenlenmesiyle nedeniyle kritik bir dönüm noktasıdır.

Uzun bir hazırlık süreci sonrasında 2010 yılında Başbakanlığa bağlı olarak kurulan Yurtdışı Türkler ve Akraba Toplulukları Başkanlığı (YTB) kurumsallaşma ve koordinasyon bağlamında yaşanan değişikliğin somutlaştı̆̆ı kurumdur. Yurtdışına göç etmiş vatandaşların, soydaş olarak ifade edilen toplulukların ve Türkiye'ye gelen öğrencilerin yönetimini aynı çatı altında toplayan başkanlık, "Nerede bir vatandaşımız ve soydaşımız varsa, biz oradayız!” sloganıyla, Türkiye'nin ulusaşırı alanda kurmak istediği çok katmanlı üyelik politikasının temelinde var olmuştur. Önceki dönemlerdeki yaklaşımdan ayrışan bu politika bağlamında Türkiye'den göç etmiş vatandaşlar ile Türkiye'yle etnik-dini bağlar üzerinden tanımlanan soydaşlar aynı kurumsal mekanizmaların altında bir araya getirilmektedir. ${ }^{38}$ YTB’nin koordinatör üst kurum kimliği çerçevesinde yüklendiği çeşitli işlevler arasında özellikle üçünün altı çizilmelidir: 1) sivil toplum kuruluşlarına yönelik kapasite geliştirme programları ve fon sağlanması, 2) yurtdışındaki vatandaşlara yönelik meselelerde stratejilerin belirlenmesi ve kanun yapıcılara yönelik savunuculuk (örneğin Türkiye'deki seçimlere uzaktan katılım konusu), 3) Yurtdışı Vatandaş Danışma Kurulu vasıtasıyla devlet-(sivil) toplum iletişimi, izleme (monitoring) ve yeri geldiğinde yönlendirme yapılması. ${ }^{39}$

YTB ilk işlevi üzerinden yurtdışındaki sivil toplum alanını düzenlemeye çalışmaktadır. Üyeleri sivil toplum kuruluşları temsilcileri arasından seçilen Danışma Kurulu aracilığıyla devlet-sivil toplum iletişiminin güçlendirilmeye çalışıldığı görülmektedir. ${ }^{40}$ YTB’nin 2011'de kurulan "İmece Sivil Toplum Destekleri” programı ile başlayan ve 2015 sonrasında "Mali Destekler Programları" olarak sunulan destekleri çerçevesinde yurtdışındaki vatandaşlara farklı programlarla ulaşılmaktadır. 2015’te genişletilen Mali Destekler Programı’na ABD, Almanya, Avustralya, Avusturya, Belçika, Birleşik Krallık, Danimarka, Finlandiya, Fransa, Hollanda, İsveç, İsviçre, İtalya, Kanada ve Norveç'ten sivil toplum kuruluşları, üniversiteler, uluslararası kuruluşlar, düşünce kuruluşları ve araştırma merkezleri başvurabilmektedir. Proje çağrısında yer alan ayrımcılık, aktif yurttaşlık, siyasi, sosyal, ekonomik katılım, çift dillilik gibi çalışma alanları, yurtdışındaki vatandaşlara yönelik öncelikli konuları karşımıza çıartmaktadır. ${ }^{41}$

Yurtdışına göçün ivme kazandığı 1960’lı yıllardan itibaren Türkiye devletinin göçmenlere ve yurtdışındaki vatandaşlarına yönelik yaklaşımını kısaca üç farklı dönem altında toplamak mümkündür: 1960'tan 1980 darbesine kadar olan ilk ekonomik faydacı-bölgesel sahiplenme eğilimli dönem, 1980'den 1990'ların sonuna kadar olan kültür-odaklı geçiş dönemi ve 1990'ların ikinci yarısı ve özellikle 2000 'lerin başından itibaren ortaya çıkan hem diaspora yaratma söylemi etrafında kurumsallaşma ve ulusaşırı genişletilmiş vatandaşlık hedefli dönem. Vatandaşların ikamet ettikleri ülkelerde kalıcı olmalarının tanınması, çifte vatandaşlık politikalarının yaygınlaşması ve ilişkinin

38 Damla B. Aksel, “Kins, Distant Workers, Diasporas: Constructing Turkey's Transnational Members Abroad”, Turkish Studies, Cilt 15, No.2, 2014, s.195-219.

39 Damla B. Aksel, “Kins, Distant Workers, Diasporas”.

402012 yılında seçilen Yurtdışı Vatandaş Danışma Kurulu’nun üyeleri devlet tarafından Türkiye vatandaşları ve soydaşları temsil etmek üzere 19 ülke/bölgedeki sivil toplum temsilcilerinin yanı sıra farklı devlet kurumları temsilcilerini içermektedir. Her bir ülke/bölgeyi temsil edecek kişi sayısı, ülkelerin nüfusunun yanı sıra temsil edilecek ülkelerin politik önemini ortaya koymaktadır. Bu bağlamda ilk sırada Almanya (18), ABD (8), Fransa (6), Hollanda (4) ve Balkanlar (4) bulunmaktadır. Danışma Kurulu'na ek olarak belirlenmiş Onur Üyeleri arasında ABD, Almanya, Avusturya, Fransa, Hollanda, İngiltere ve Kanada'dan temsilciler yer almaktadır.

41 Bkz. http://www.ytb.gov.tr/tr/mali-destekler/847-mali-destekler. 
ulusaşırı alana genişlemesi 1980 'lerdeki geçiş süreciyle başlamış, son yıllarda aktif siyasi vatandaşlığa doğru şekillenmiştir. Sivil toplum alanına dair yapılan düzenlemeler açısından bakıldığında ise Avrupa Birliği adaylık sürecinin etkisiyle uluslararası arenayla etkileşimin yolunun açıldığı anlaşılmaktadır. $\mathrm{Bu}$ durumla ilişkili olarak Türkiye devletinin hem bir yandan yurtdışında yaşayan vatandaşlarının yarattığı ulusaşırı sivil toplum alanına dâhil olmaya, hem de diasporik üyelik çerçevesinde alanı yeniden yapılandırmaya çalıştığı görülmektedir. Devletin ulusaşırı sivil toplum alanına dair politikalarını anlatan bu bölümü tamamlaması açısından bir sonraki bölümde yurtdışında yaşayan Türkiye kökenlilerin ulusaşırı sivil toplum alanındaki uygulamaları ve devletle olan ilişkileri ele alınacaktır.

\section{Yurtdışındaki Türkiye Kökenliler ve Ulusaşırı Sivil Toplum Pratikleri}

Türkiye'den yurtdışına göç, erken Cumhuriyet döneminden itibaren farklı örüntülerle ve farklı coğrafyalara yönelik olarak gelişmiştir. Bu göç süreçlerinden niceliksel olarak ön plana çıkanlarını beş farklı dönem altında sınıflandırmak mümkündür: 1) Özellikle gayri-Müslim grupların 19. yüzyılın sonundan itibaren Kuzey Amerika’ya ve Avrupa'ya yönelik göç hareketleri, 2) 1960’lardan 1970’lerin ortasına uzanan Avrupa ve Avustralya’ya yönelik yoğun işçi ve aile birleşimi göçleri, 3) 1980 darbesi sonrası yaşanan siyasal göçler, 4) 1980’lerde Orta Doğu ve Kuzey Afrika'ya, 1990’lardan itibaren de eski Sovyet ülkelerine yönelik kısa süreli vasıflı işçi hareketliliği ve 5) Son olarak 1990’lardan itibaren hem coğrafi olarak (Avrupa, ABD, Kanada ve Avustralya'ya yönelik), hem de biçim olarak (öğrenci ve profesyonel göçleri gibi yeni göç örüntüleriyle birlikte) çeşitlenen göçmen hareketlilikleri. Bu farklı dönemler, hem yurtdışında yaşayan Türkiye kökenli vatandaşların gündelik, sosyal, siyasi, ekonomik etkinliklerini anlamlandırmak, hem de Türkiye devletiyle olan ilişkilerini anlamlandırmak açısından önem taşımaktadır.

Tablo 1 Türkiye Kökenliler Tarafından Kurulan Dernekler ve Türkiye Cumhuriyeti Vatandaşları

\begin{tabular}{|l|c|c|}
\hline \multicolumn{1}{|c|}{ Ülke } & Dernek Sayısi & Vatandaş Sayısi \\
\hline Almanya & 5300 & 1.629 .480 \\
\hline Fransa & 583 & 553.979 \\
\hline Hollanda & $\sim 230$ & 358.846 \\
\hline ABD & 193 & 199.000 \\
\hline Avusturya & $\sim 130$ & 159.038 \\
\hline İsviçre & 95 & 71.039 \\
\hline Belçika & $\sim 85$ & 39.885 \\
\hline Avusturalya & $\sim 80$ & 63.000 \\
\hline İngiltere & $\sim 30$ & 52.893 \\
\hline
\end{tabular}

Kaynak: Çalışma ve Sosyal Güvenlik Bakanlığı Dış İlişkiler ve Yurtdışı İşçi Hizmetleri Genel Müdürlüğ̈ internet sayfasından, ÇSGB raporlarından ve Amerika Türk Koalisyonunun (TCA) listesinden derlenmiştir.

Türkiye'den yurtdışına göç konusu söz konusu olduğunda akla ilk gelen ülke, hiç şüphesiz Türkiye kökenli nüfusun en yoğun olduğu Almanya'dır. Yarısı halen köken ülke vatandaşı olan üç milyondan fazla kişiyi barındıran Türkiye kökenli toplum, 1961 yılında iki ülke arasında imzalanan karşılıklı işgücü anlaşması sonrası başlayan ve onu takip eden göç akımlarıyla birlikte gidenler ve onları takip eden nesillerden oluşmaktadır. Bu yoğun ve parçalı gruplar halinde var olan topluluk, 
Türkiye devletinin yurtdışındaki vatandaş siyaseti açısından göçün ilk dönemlerinden itibaren başrol oynamaktadır. Almanya'daki sivil toplum alanına bakıldığında, nüfus yoğunluğuna paralel bir hareketlilikten söz etmek mümkündür. Çalışma ve Sosyal Güvenlik Bakanlığı’nın güncel verilerine göre, Türkiye kökenli kişilerce kurulan 5300 derneğin 3700’ü dini, siyasi, sosyal, kültürel amaçlı derneklerden oluşurken; 400 dernek sportif amaçlı, 1200'ü ise işveren ve okul aile birlikleri gibi amaçlarla kurulmuş derneklerdir. ${ }^{42}$ Türkiye kökenli dernekler, Almanya çapında çeşitli hizmetlerin sunulduğu ve sol-sağ ideolojik çizgisinin her noktasından farklı taleplerin ifade edildiği başlı başına önemli bir sivil toplum alanı yaratmaktadır. 2000'lerin başında yayınladığı çalışmalarında ØstergaardNielsen, Türk devletini destekleyen ya da karşı çıkan ve çoğu aktif bir şekilde ulusaşırı siyaset yapmaya devam eden örgütlenmelerin varlığından söz eder. ${ }^{43}$ Bu makale açısından, Almanya'daki sivil toplum ortamının ulusaşırı siyasal hareketlerin şiddetlendiği 1970'li yıllardan itibaren başta Avrupa çapında olmak üzere pek çok ülkede ortaya çıan farklı örgütlenmeleri bir araya getiren merkez rolü edinmiş olması daha da önem taşımaktadır. Bu çatı örgütlenmeler (federasyonlar, konfederasyonlar) arasında, Demokratik İşçi Dernekleri Federasyonu’ndan (DIDF) Türk Federasyonu ve Milli Görüş'e, Avrupa Alevi Birlik Federasyonu'ndan Kürdistan Dernekleri Birliği'ne (KOMKAR) çok sayıda örgütlü yapı bulunmaktadır.

Avrupa'daki göçmen topluluklarının ulusaşırı pratikleri üzerine var olan literatürdeki ilk sistemli çalışmalar arasında Argun ${ }^{44}$, Østergaard-Nielsen ${ }^{45}$ ve Ögelman' ${ }^{46}{ }^{46}$ Almanya'daki Türkiye kökenli Türk ve Kürtler'in ulusaşırı siyasi pratikleri konusundaki çalışmaları sayılabilir. Østergaard-Nielsen'e göre, Avrupa'ya dair çalışmalarda, uzun bir süre göçmenlerin siyasi ve sosyal katılımlarını sadece ikamet ettikleri ülke politikaları çerçevesinde değerlendirmiş, köken ülkedeki farklı aktörlerle kurulan ulusaşırı ağ ve köken devletle ilişkili meseleler göz ardı edilmiştir. ${ }^{47}$ Çalışmalar, Almanya örneği üzerinden, bu ağların da etkili olduğunu ortaya koymaktadır. Ortaya çıkan siyasi ayrışmalardan, göçmenlerin katılım pratikleri ve köken devletle kurdukları ilişkilere kadar pek çok meselenin ardında Türkiye'yle ilişkileri de içeren ulusaşırı ağlara içkin durumlar yatmaktadır. Østergaard-Nielsen, bu bağlamda yaptığı değerlendirmelerini üç örnek üzerinden şekillendirmektedir: 1999 sonrası Kürt hareketinin Almanya'yı bir savunuculuk alanına çevirmesi; 1998-1999 yıllarında Hristiyan Demokrat Birliği’nin (CDU) ulusaşırı siyasi pratiklerin Alman toplumunda yeri olmadığını belirterek çifte vatandaşlığa karşı pozisyon alması ve son olarak İslami örgütlerin Türkiye'deki siyasi partilerle olan ilişkilerini sorgulaması. ${ }^{48}$ Köken ülkelere dair meselelerin göçmenler üzerindeki yansımaları yakın dönemdeki çalışmalarda da ele alınmaktadır. Köken ülkeye yönelik göçmen yatırımları ve insani yardım projeleri üzerine araştırmaları bulunan Sezgin, Türkiye siyasetine atıfta bulunmayan sivil toplum örgütlerinin neredeyse yok denecek kadar az olduğunu ortaya koymaktadır. ${ }^{49}$ Kaya ve Kentel'in çalışması, Türkiye devlet kurumları tarafından göçmenlerin siyasi alana katılımını teşvik etmeyi hedefleyen faaliyetlerin, göçmenler arasında ideolojik çekişmeye ve diasporayı temsil eden tek grup olma iddiasıyla rekabet

42 http://www.csgb.gov.tr/csgbPortal/diyih.portal?page=ulkeler\&id=almanya

43 Østergaard-Nielsen, Transnational Politics.

44 Argun, Turkey in Germany.

45 Østergaard-Nielsen, Transnational Politics.

46 Ibid.

47 Nedim Ögelman, "Documenting And Explaining The Persistence Of Homeland Politics Among Germany's Turks", International Migration Review, Cilt 37, No.1, 2003, s.163-193.

48 Østergaard-Nielsen, Transnational Politics, s.7-8.

49 Zeynep Sezgin, “Turkish Migrants' Organizations in Germany and Their Role in the Flow of Remittances to Turkey”, Journal of International Migration and Integration, Cilt 12, No.3, 2011, s.231-251. 
etmelerine yol açtığını göstermektedir. ${ }^{50}$ Kaya’nın bunu takip eden çalışmalarında da bahsedildiği gibi, bu durum pek çoğu köken ülkeleri ile yaşadıkları ülkeler arasında mekik dokuyan ulusaşırı göçmenlerin yeni kimlikler inşa etme süreçlerine etki etmektedir. ${ }^{51}$ Başer ise Türkiye'de süregelen etnik çatışmanın aileleri Türkiye kökenli ikinci nesil Türk ve Kürtlere miras kaldığını, ötekileştirmenin yeniden şekillendirildiğini ve yaratıldığını ortaya koymaktadır. ${ }^{52}$

Türkiye'den Avrupa'ya yönelik göç içerisinde en kalabalık ikinci nüfusu barındıran Fransa'da 600 bine yakın Türkiye kökenli kişi olduğu bilinmektedir. Fransa’ya yönelik göç 1965'de imzalanan işgücü anlaşması ile birlikte başlamışsa da, bugünkü nüfusun çoğunluğunu teşkil eden hareketlilik 1970’lerin ikinci yarısı ile 1980’ler boyunca ortaya çıkmıştır. Göçün zamanı ve şartları Fransa'da oluşan sivil toplum alanı açısından belirleyicidir. Zira erken dönemde diğer Avrupa ülkelerine nazaran Fransa'ya daha az vasıflı olan işçiler akın ederken, 1980'lerdeki sosyalist Mitterand hükümetinin de etkisiyle ülke hem yoğun bir mülteci hem de Almanya gibi ülkelerde oturma izni edinemeyen Türkiye kökenli kişilerin akınına maruz kalmıştır. Fransa’da 1980’lerde gelişen işçi ve göçmen hakları eylemlerinin Türkiye'ye yönelik siyasetle bir araya gelmesi sonucunda önemli bir sol hareketlenme ve örgütlenmenin oluştuğundan söz edilebilir. Bu hareketlilik içerisinden doğan bir grup, 1990’larda sağa eğilimli dernekleri de içine katarak, çok kültürlülük ve Türkiye’nin Avrupa Birliği süreçlerine katılımı konularına odaklanmıştır. ${ }^{53}$ Yine de kapalı cemaatleşmeler etrafında toplanan toplumun geneli için, Fransa'daki katı cumhuriyetçi değerleri benimseyen entelektüel bir kesim tarafından "entegre olması en zor topluluk" ifadesinin kullanıldığı da belirtilmelidir. ${ }^{54}$

Fransa'daki Türkiye kökenli kişiler tarafından kurulan dernek ve vakıf yapılarına bakıldığında, Almanya'dakine benzer derin politik ayrışmalar (başta keskin bir şekilde herkesin alanını bildiği solsağ ayrışması) ve bu ayrışmaya eklemlenen dini, etnik ve ideolojik çatışmalar bulunduğu görülür. Sivil toplum alanında Fransa'da son yıllarda yaşanan dönüşümlerden ilki, devlet ile iletişim olanaklarının ve talep alanının genişlemesine yol açan, Türk Dışişleri Bakanlığı bünyesindeki politika değişikliği olmuştur. ${ }^{55}$ Köken devlet ile sivil toplum ilişkileri alanında bu şekilde yeni bir iletişim ve karşılıklı temsiliyet alanı yaratılmışsa da devletin alana dâhil ettiği aktörler bağlamında seçicilik esası üzerinden hareket ettiğini vurgulamak gerekir. Zira daha önce bahsedilen "makbuller" ve "makbul olmayanlar" ayrımı bu süreç içerisinde bir kez daha ön plana çıkmakta, var olan alan genişletilmiş olsa da vatandaşlık bağı olan her grup ilişki ağının içerine gir(e)memektedir. Konuya Fransa'da var olan ideolojik ayrışmalar çerçevesinden bakıldığında ise devlet yapılarının sol yönelimden ziyade sağ kanatta yer alan sivil toplum alanıyla daha yakınlaştığı ortaya çıkmaktadır. İsveç'tekine benzer şekilde geçmişte Kürt meselesi bağlamında yaşanan bu yakınlaşma, son yıllarda kendisini Ermeni meselesi tartışmaları

50 Ayhan Kaya ve Ferhat Kentel, Euro-Turks: A Bridge or a Breach between Turkey and the European Union?, Brüksel, Centre for European Policy Studies, 2005.

51 Ayhan Kaya, “German-Turkish Transnational Space: A Separate Space of Their Own”, German Studies Review, Cilt 30, No.3, 2007, s.483-502.

52 Bahar Başer, Diasporas And Homeland Conflicts: A Comparative Perspective, Ashgate Publishing, 2015, s.5.

531991 yılında kurulan Conseil Français des Associations d’Immigrés de Turquie (Fransa Türkiyeli Göçmen Dernekleri Konseyi) göçmenlerin Fransız toplumuna katılımını kolaylaştırmak amacını taşımaktadır. 1990'lar boyunca Gözlem/ L'Observateur ve Altyazı/Multitudes gibi yayınlar yapan ve seminerler düzenleyen konseyin odağında, slogan haline getirilmiş iki mesele bulunmaktadır: "Her türlü ayrımcılık, dışlama ve ırkçılığa karşı” olmak, "Eşit haklar ve yeni bir yurttaşlık için” mücadele vermek. Konseyin, kapandığı 2007 yılına kadar sol eğilimli, Kemalist ve sağ hareketlere yakın olmak üzere farklı ideolojik yaklaşımlardan dernek üyeleri olmuştur.

54 Michele Tribalat, De l'Immigration al'assimilation: Enquête Sur Les Populations d'Origine Étrangère En France, Paris, La Découverte/INED, 1996.

55 Damla B. Aksel, Home States and Homeland Politics: Interactions between Turkish State and Its Emigrants in France and the United States, Yayınlanmamış Doktora Tezi, İstanbul, Koç Universitesi, 2016. 
çerçevesinde belli etmiştir. 2011-2012 yıllarında Fransa'da gündeme gelen Ermeni soykırımını inkâr yasasına karşı ses getiren bir söylem ve siyasallaşma hareketine gidildiği görülmektedir. Bu bağlamda 2012'de Fransa Türk Dernekleri Koordinasyon Birliği adında tek bir çatı altında toplanan farklı sivil toplum kuruluşlarının düzenlediği protestolara temsilcilikler ve Yurtdışı Türkler Başkanlığı da destek vermiştir. $^{56}$

Mügge, Hollanda’daki Türk ve Kürt göçmenleri ele aldığı çalışmasında, Türkiye kökenli göçmen dernekleri arasındaki ağın kuvvetli ve yoğun yapılar oluşturduğunu belirtmektedir. ${ }^{57}$ Pek çoğu başta Almanya ve Belçika'daki konfederasyonlar olmak üzere diğer ülkelerle ulusaşırı ağlar içerinde yer alan Türkiye kökenli dernekler, Mügge'ye göre, temel örgütlenmeler etrafında kümelenmiştir. Bunlar arasında Diyanet, Alevi örgütlenmeleri, Kürt örgütlenmeleri, Türk Federasyonu, Sosyal Demokratlar, Milli Görüş, radikal sol örgütler ve Hollanda hükümetinin desteğiyle 1985 yılında dört Türk derneğini temsil etmek için kurulan ve Türk hükümetiyle ad hoc iletişim halinde olan Hollanda'da Türkler için Danışma Kurulu (IOT) yer almaktadır. ${ }^{58}$ Mügge'ye göre IOT, hem Hollanda Devleti hem de Türkiye Devleti arasında köprü rolü oynamak ve Hollanda'daki bütün dernekleri temsil etmek amacıyla kurulmuş olsa da yıllar içerisinde Türkiye'yle ilişkili meseleler nedeniyle farklı kurumlarla yaşanan çatışmalara sebep olmuş ve Türkiye siyasetinden etkilenmiştir. ${ }^{59} \mathrm{Bu}$ durumu etkileyen faktörler arasında 1980'lerin ortasından itibaren kalkan siyaset yasağının göçmen derneklerini yoğun bir biçimde Türk siyasi partilerinin faaliyetlerine maruz bırakması özellikle belirtilmelidir. Siyasi partilerin yurtdışı örgütlenmelerini engelleyen yasa 1995'de değiştirilmiş olsa da pek çok kurum resmi olmayan ağlar aracılı̆̆ıyla resmi olmayan bir şekilde partilerin temsilcileri konumuna gelmiştir. Bu bağlamda pek çok ulusaşırı çoklu ilişki ağlarının 1990'larda ortaya çıktığı söylenebilir. Bunlar arasında Diyanet ve temsilcilikler üzerinden devletle kurulan kurumsal ilişkiler, Türkiye'deki resmi ve resmi olmayan partilerle kurulan ilişkiler üzerinden süregelen siyasal hareketlilik ve Avrupa'daki çatı örgütlerle bir arada ortaya çıkan yatay örgütlenmeler sayılabilir. Mügge, 2000’lerde başlayan politika dönüşümünün yansıması olarak, Türkiye'nin Avrupa'daki imajının değiştirilme çalışması, AB üyeliği ve Kürt hareketine karşı yanıt verme gibi köken ülkeye ilişkin meselelerin öne çıkmaya başladığını belirtmektedir. ${ }^{60}$

İsveç'te yaşayan Türkiye kökenli toplum üzerine çalışan Başer, son yıllarda Türk devleti ile diaspora aktörleri arasında artan ilişki akışının kökeninde, İsveç’te yaşayan toplumda yaşanan “diasporik uyanışın" olduğunu ileri sürmektedir. ${ }^{61}$ Başer'e göre, Avrupa'daki diğer ülkelerle benzer geçmişe sahip olan İsveç'te, başta Kürt gruplar ve Süryaniler çeşitli gruplar 1980’lerden itibaren kimlik ve insan hakları temelli talepler üzerinden yoğun bir dernekleşme hareketi içerisine girmiş ve bu şekilde İsveç’teki sosyal ve siyasal hayatta görünürlük kazanmışlardır. Buna karşıllı Türk kökenlilerin sivil toplum kuruluşları çevresinde bir araya gelmesi konusu, yakın zamana kadar, sadece hemşerilik dernekleri ve kültürel odaklı yaklaşım çerçevesinde sınırlı kalmıştır. Başer'e göre bu sınırlılığın nedenlerinden biri Türk göçmenler arasındaki entegrasyon tartışmaları üzerinden oluşan ayrışmaların, sivil toplum hareketlerine de yansımış olmasıdır. 1990’larda İsveç Türk Dernekleri Federasyonu’nun

56 Ibid.

57 Liza Mügge, Beyond Dutch Borders. Transnational Politics Among Colonial Migrants, Guest Workers And The Second Generation,. IMISCOE Research, Amsterdam University Press, 2010.

58 Ibid, s. 105.

59 Ibid, s. 107.

60 Ibid, 179.

61 Bahar Başer, "The Awakening of a Latent Diaspora: The Political Mobilization of First and Second Generation Turkish Migrants in Sweden”, Ethnopolitics, Cilt13, No.4, 2014, s.4. 
(TRF) kurulmasıyla yeşeren sivil toplum ortamı, entegrasyonu destekleyen İsveç-Türk Federasyonu (STRF), Gençlik Derneği (TUF) ve Öğrenci Derneği'nin (TSAF) kurulmasıyla çeşitlilik kazanmıştır. ${ }^{62}$ Çalışmada, kuruldukları dönemde göçmen politikaları ve entegrasyon tartışmalarına odaklanan bu derneklerin, 2000'li yıllar itibariyle önce Kürt diasporik hareketine ardından da Ermeni Soykırım Yasası'na yanıt vermek amacıyla siyasallaşmaya başladıkları ortaya konmaktadır. Bu yapılar bir yandan Türk devletiyle ilişkilerini güçlendirirken, diğer yandan da hem toplumsal hareketler yoluyla sokakta, hem de sandık üzerinden seçim siyaseti çerçevesinde siyasal alandaki gündemlerini kamuoyuna yansıtmaya başlamışlardır.

Önceki paragraflarda anlatılan Almanya, Fransa, Hollanda ve İsveç örneklerinde görüldüğü gibi iki işgücü anlaşması Avrupa'ya yönelik göç hareketi ve dolayısıyla daha sonra yeşeren sivil toplum alanı açısından belirleyici olmuştur. 1980 darbesini takip eden dönemde ideolojik ve etnik nedenlerle Avrupa'ya sığınan kitlenin ve bu kitle ile birlikte taşınan meselelerin de ortaya çıkan kimlik çatışmalarının şekillenmesine etkisi büyüktür.

Yurtdışındaki vatandaşların sivil toplum hareketlerine dair bu bölümün ikinci kısmı, Avrupa kıtasının dışındaki üç ülkeye odaklanacaktır: Amerika Birleşik Devletleri, Kanada ve Avustralya. Avustralya’nın göç geçmişinde de işgücü olması, Avrupa'dakine benzer bir kitlenin burada oluşmasını beraberinde getirmiştir. Ancak Kanada ve ABD'ye yönelik hareketliliğin temelinde kentsoylu, eğitim ve profesyonel amaçlar nedeniyle göç etmeyi tercih eden kişiler bulunmaktadır ve bu nedenle oluşan sivil toplum alanı diğer ülkelerden farklılaşmaktadır. Bu üç ülke, hem Türkiye'ye coğrafi olarak uzaktır, hem de Avrupa'da gelişen ulusaşırı toplumsal hareketlerden uzak kalmıştır. Buna rağmen, yine de Türkiye'de yaşanan siyasi gelişmelerin ve Türkiye'nin göç ve yurtdışı vatandaş politikalarının Avrupa'daki benzer dönemlerde yaşananlara benzer dönüşümlere yol açtığı görülmektedir.

Amerika Birleşik Devletleri’ne Türkiye coğrafyasından göç, yurtdışına kitlesel göçün başlangıcı olarak kabul edilen 1960'lardan çok daha önceleri başlamışsa da günümüzde Türkiye vatandaşlığı çerçevesinde ulusaşırı pratiklerini sürdüren kitlelerin göç süreçleri yine 1960'ları bulmuştur. 19. yüzyılın sonu ve 20. yüzyılın başında çoğunluğu Ermeni ve Rumlar'dan oluşan bir kitle ekonomik beklentiler ve yaşanan siyasi çatışmaların sonucunda Amerika'ya sığınmıştır. Bu erken dönem gidenler arasında Cumhuriyet'in kuruluşunu takip eden dönemde Türkiye'ye geri dönmüş mavi yakalı etnik Türk bir grup da bulunmaktadır. Anadolu'dan ABD'ye yönelik erken göç hareketliliğine dair tartışmalar arasında ulusaşırı ağların ve pratiklerin geçmişte de var olduğunu ortaya koyan örnekler mevcuttur. Kurtuluş Savaşı'nın başladığı yıllarda ABD’ye siyasi nedenlerle gidenler arasında mavi yakalı Türk ve Kürtleri işçi hakları üzerinden örgütlemeye çalışan ve hatta bu örgütlenmeler üzerinden savaşta öksüz-yetim kalmış çocuklar için sığınma evleri kurulması için para toplayan kişiler olduğu bilinmektedir. ${ }^{63}$

Akçapar, ABD’deki Türkiye kökenli göçmenlerle ilgili çalışmalarında, kültürel etkinlikler etrafında yeşeren sivil toplum hareketliliğinin, 1970'lerde ortaya çıkan ve Türkiye devletini hedef alan Yunan ve Ermeni siyasi hareketleri sonrası siyasallaşmaya başladığını belirtir. ${ }^{64}$ Türkiye devletinin göçmenleri birleştirici yaklaşımı, diğer ülke örneklerinde, özellikle dini ve milliyetçi bir söylem üzerinden kültürel odaklı bir çerçevede kurulurken, Amerika örneğinde siyaset ve lobi oluşturma beklentisi, karalama-karşıtlı̆ı çerçevesinde ve 1980 'lerde şekillenmiştir. Avrupa ve Amerika'daki

62 Ibid, s.9.

63 Sabiha Sertel, Roman Gibi, İstanbul, Belge Yayınları, 1969.

64 Şebnem K. Akçapar, "Turkish Associations in the United States: Towards Building a Transnational Identity”, Turkish Studies, Cilt 10, No.2, 2009, s.180. 
örgütlenmelerin bir karşılaştırmasını yapan Akçapar, Avrupa'daki göç alan topluma yönelik kendini koruma hedefli derneklere karşılık Amerika'da diğer etnik azınlıklar ve diasporalara yönelik bir örgütlenmenin ortaya çıktığını ifade etmektedir. ${ }^{65} \mathrm{Bu}$ siyasallaşma, son yıllarda köken devlet söyleminin benimsendiği, yeniden kurgulanarak tekrarlandığı, yeni kurumların da ortaya çıkmasını beraberinde getirmiştir. Örneğin 2007 yılında Washington'da kurulan Amerikan Türk Koalisyonu (TCA) Türk Amerikalıların tanınmasını, görüşlerinin duyurulmasını, haklarının korunmasını ve Amerika’da faaliyet gösteren Türk derneklerinin koordinasyon içerisinde çalışmasını hedeflerken, aynı zamanda Türkiye'nin ABD'de tanınması ve iki ülke arasındaki işbirliğinin geliştirilmesini de amaçlamaktadır. Koalisyon, eğitim yoluyla Türk-Amerikan meselelerinin tanıtılması hedefi çerçevesinde ABD Kongresi ile yakın ilişkiler kurmaktadır. ${ }^{66}$

Kanada'daki göçmen dernekleriyle ilgili çalışmasında Özçürümez, Türkiye kökenli kişilerin siyasi katılımının henüz emekleme aşamasında olduğunu savunmaktadır. ${ }^{67}$ Özçürümez’e göre, Amerika örneğine benzer şekilde, Kanada'da yaşayan Türklerin nüfus azlı̆̆ı ve geniş bir coğrafya içerisinde seyrek olarak dağılmış olması yakın zamana kadar etkili bir örgütlenmenin ortaya çıkmasını engellemiştir. ${ }^{68}$ Türkiye'den Kanada'ya göçün tarihine bakıldığında, İkinci Dünya Savaşı sonrasında başlayan bir hareketlilikten ve 1960-1970'lerde hızlanan, kent kökenli profesyonellerden oluşan bir göç örüntüsü görülmektedir. Yine ABD'deki göç geçmişine benzer şekilde, Batılı ve modernleşme süreçlerinden etkilenmiş cumhuriyet çocuklarının ve öğrencilerin Kanada'yı tercih ettiği ortaya çıkmaktadır. Dernekleşme hareketlerine bakıldığında, 1960'ların ortasında entegrasyon konularına odaklanan Türk Kanada Dostluk Cemiyeti etrafında ortaya çıkan örgütlenmenin, 1970’lerde kültürel odaklı derneklerle yaygınlaşmaya başladığı, 1980'lerde ise göçmen ve mülteci haklarına odaklı siyasi ve toplumsal hareketlere dönüştüğ̈ görülmektedir. Özçürümez’e göre, son yıllarda iki büyük dernek - Türkiye’yle ilişkili konularda Kanadalı karar alıcılara yönelik savunuculuk faaliyetleri gerçekleştiren Turquebec ile din ve kültür meselelerine odaklanan Quebec Türk Kültür Derneği- Kanada'daki farklı kesimleri temsil etmektedir. ${ }^{69}$ Özçürümez, Başer’in İsveç örneğine benzer şekilde, geçmişte kültürel meselelere odaklanmış olan sivil toplum hareketliliğinin son yıllarda hem Türkiye'yle ilişkili meselelere (Kıbrıs meselesi ve Ermeni soykırım tartışmaları) hem de Kanada'daki siyasi hayata katılımla alakalı konulara (2007 Quebec yerel seçimlerine katılım çağrısı gibi) yönelik olarak hareketlendiğini ortaya koymaktadır.

Şenay, Avustralya'daki Türk göçmenler üzerine yaptığı çalışmalarında, devlet ve göçmenler arasındaki ilişkiyi önceki çalışmalara kıyasla daha derinden irdelemektedir. ${ }^{70}$ Avustralya'da yaşayan göçmenlerin, aradaki uzak mesafeye rağmen, Türkiye'de süregelen siyasi ortamdan etkilendiğini belirten Şenay, 1970 ve 1980 'lerin sağ-sol ayrışmasının sonucunda Avustralya'da sosyal demokrat ve kimi Kemalist dernekleri de içeren sol eğilimli yapılar ile İslam ve Türklük kimliği etrafında şekillenen sağ eğilimli yapıların ortaya çıtığını belirtmektedir. Göçmenlerle hem göçmen gönderen hem de göçmen alan ülke arasındakiilişkiler kolektif alanlarda belirmektedir. Örneğin Auburn Gelibolu Camisi, bir yandan Türkiye'den Sydney’e Diyanet aracılığıyla aktarılan sürekli bilgi akışına sahne olurken, diğer yandan da Avustralya devlet kurumlarının çok kültürlülük politikasından etkilenmektedir. Her iki

65 Ibid.

66 Aksel, Home States and Homeland Politics.

67 Saime Özçürümez, "Immigrant Associations In Canada: Included, Accommodated, Or Excluded?", Turkish Studies, Cilt 10, No.2, 2009, s.195-215.

68 Ibid.

69 Ibid.

70 Banu Şenay, “Trans-Kemalism: The Politics Of The Turkish State in The Diaspora”, Ethnic and Racial Studies, Cilt 35, No.9, 2012, s.1615-1633. 
ortamdan da faydalanan cami, eğitsel faaliyetler, seminerler, festivaller gibi pek çok etkinlik dolayısıyla bir sivil toplum kuruluşu gibi hareket etme niteliği kazanmıştır. Başkonsolosluk her firsatta kültürel, sanatsal, sportif etkinlik konularında duyurular yapmanın yanı sıra, Türkiye'ye yönelik "anavatan" söylemini kullanarak burada yaşayan vatandaşların özellikle Ermeni grupları ile yaşanan çatışmalar konusunda “Türkiye’nin gönüllü temsilcileri” olduğunu hatırlatmaktadır. Şenay’a göre Avustralya kıtasındaki Türklük ve Türk milliyetçiliği, bu örnekte olduğu gibi, Türkiye devletinin Avustralya'daki Türk göçmenlere yönelik siyasi ulusaşırı pratiklerinin yanında, göçmenlerin tabandan oluşturduğu süreçlerle de şekillenmektedir. Şenay'ın ulusaşırı Kemalizm olarak tanımladığı bu süreçte, göçmenler kendilerini etnik, kültürel ve dini değerlere karşı konumlandırmaktadır. ${ }^{71}$

Türkiye’den yurtdışına yönelik olan göç örüntüleri farklı dönemlerde farklı nedenler ve motivasyonlarla ülkeyi terk eden göçmen gruplarını içermektedir. Bu göç örüntüleri, aynı zamanda göçmenler, entegrasyon, vatandaşlık ve katılım konularında da yapısal olarak önemli farklılıklar taşıyan ülkelere yöneliktir. Bugüne kadar yapılan çalışmalar bağlamında baktığımızda, göç süreçlerinin, göçmenlerin sosyoekonomik özelliklerinin ve göç edilen ülkelerin yapısal şartlarına bağlı olarak değişiklik göstermekle birlikte çeşitli benzerlikler taşıdığı da görülmektedir.

Literatüre yansıyan bu benzerliklerden ilki, kitlesel göç süreçlerinin başından itibaren Türkiye'deki siyasi ortamdan etkilenmesi neticesinde parçalanmış bir sivil toplum alanının ortaya çıkmasıdır. Farklı ülkelerde sol-sağ ayrımı ile başlayıp daha sonra Türk-Kürt, Alevi-Sünni ve dindar-laik ayrımı gibi çeşitlenen benzer ayrışmaların yaşanmış olması bu durumu vurgulamaktadır. Türkiye'de bahsi geçen konulara dair siyasi çalkantıların yaşandığı dönemlerde, yurtdışındaki vatandaşların ulusaşırı pratikleri ve meseleleri çerçevelendirmesinde de dönüşüm yaşanmıştır. Ayrıca bahsedilen ayrımın etkisiyle, özellikle Avrupa coğrafyasında, 1980'ler ve 1990’larda yeşeren ve güçlenen ulusaşırı bir sivil toplum ağı ortaya çıkmıştır. İncelenen farklı araştırmalardan ortaya çıkan bir diğer benzerlik ise Türkiye devleti tarafindan da desteklenen Türkiye kökenli belli grupları bir arada toplamaya yönelik girişimlerin varlığıdır. Bu girişimler kendisini cami ve eğitim kurumları gibi dini ve kültürel alanlarda gösterebildiği gibi, federatif yapısı olan sivil toplum kuruluşları bağlamında da ortaya çıkabilmektedir. Nitekim bir araya getirilmeye çalışılan bu hayali toplumun homojen olmaması ve temel söylemin milliyetçilik üzerinden inşa edilmiş olması nedeniyle girişimlerin çoğunluğu ya küçük kitleleri mobilize edebilmekte ya da göçmen alan devlet ve toplum tarafından sert eleştirilere maruz bırakılmaktadır. Son olarak, Türkiye devletinin yurtdışında resmi olmayan lobi yaratma ve onu güçlendirmeye dair beklentisinin, belli bir oranda karşılık bulduğu görülmektedir. Bu yaklaşımın hem Türkiye'yle ilişkilerde hem de ikamet edilen ülkede aktif vatandaşlık perspektifini hedeflemesi, farklı ülke örneklerinde görüldüğ̈ gibi iki eksenli bir sosyal ve siyasi hareketliliğe yol açmaktadır. Ancak Waldinger ve Fitzgerald'ında tartıştığı gibi, bu dışa dönük hareketlilik çelişkili bir şekilde belli bir aidiyet üzerinden tanımlanmış bir kapalılık arz etmektedir. ${ }^{72}$

\section{Sonuç}

$\mathrm{Bu}$ çalışma Türkiye devleti ile yurtdışındaki Türkiye kökenliler arasındaki ilişkiye bütüncül bir yaklaşım ile yaklaşmayı hedeflemiştir. Çalışmanın ilk kısmı literatüre odaklanarak, yakın zamanda ulusaşırılık ve vatandaşlık tartışmalarından da etkilenerek güçlenen köken devlet literatürü üzerinde durmuş, devletler ile göçmenler arasındaki ilişkiye dair bugüne kadar ortaya koyulmuş tezleri, özellikle

71 Ibid.

72 Waldinger ve Fitzgerald, “Transnationalism in Question”. 
sivil toplum alanı bağlamında ele almıştır. Ulusaşırılık tartışmaları bağlamında incelenmiş olan köken devlet-göçmen ilişkileri meselesi, 1990'lardan itibaren ABD'deki akademik dünyada yerini bulurken, son yıllarda yapılan çalışmalarla birlikte Avrupa coğrafyasında da göç sonrası süreçler çerçevesinde konu edilmeye başlanmıştır.

Çalışmanın ikinci kısmı, Türkiye devlet politikaları ile Türkiye kökenli göçmenlerin ulusaşırı pratiklerinin ele alındığı iki betimleyici bölümü içermektedir. Bu bölümlerden ilkinde, 1960'lardan günümüze Türkiye devletinin yurtdışındaki vatandaşlarına yönelik politikaları ortaya konulmuştur. Vatandaşların ikamet ettikleri ülkelerde kalıcı olmalarının kabullenilmesi, çifte vatandaşlık politikalarının yaygınlaşması ve devletin göçmenlere yönelik yeni politikalar benimsemesi, devletle vatandaşlar arasındaki ilişkinin ulusaşırı alana genişlemesine yol açmıştır Sivil toplum alanına yönelik olarak yapılan düzenlemeler açısından bakıldığında Avrupa Birliği adaylık sürecinin etkisiyle uluslararası alanla etkileşimin yolu açmıştır. Bu durumla ilişkili olarak Türkiye devletinin yurtdışında yaşayan vatandaşların yarattığı ulusaşırı sivil toplum alanına dâhil olmaya ve diasporik üyelik çerçevesinde onlarla olan ilişkisini yeniden yapılandırmaya çalıştığı görülmektedir.

Türkiye kökenli göçmen topluluklarının ve devletin ulusaşırı alana yönelik pratiklerinin birbirini etkileyen süreçler olarak işlediği görülmektedir. Yaratılmaya çalışılan bu alana ilişkin süreçler, devlet-toplum ilişkileri ve ulusaşırı vatandaşlık bağlamında dönüşümlerin yaşanmasında önemli rol oynamaktadır.

Çalışmanın son kısmında, Türkiye kökenli kişilerin ulusaşırı pratiklerine dair dönüşümlerden ve bu dönüşümler bağlamında Türkiye devlet politikalarının etkisinden bahsedilmiştir. Bu bölümün sonuçlarından birisi, göçün ilk dönemlerinden itibaren Türkiye'deki siyasi ortamdan etkilenerek parçalanan, sol-sağ ayrımı ile başlayıp daha sonra Türk-Kürt, Alevi-Sünni ve dindar-laik ayrımı gibi çeşitlenen ayrışmaların olduğu bir sivil toplum alanının ortaya çıkmasıdır. İkinci sonuç ise, Türkiye devletinin yurtdışında resmi olmayan lobi yaratma ve onu güçlendirmeye dair politikasının belli gruplar üzerinde hem Türkiye'yle ilişkilerde hem de ikamet ettikleri ülkelerde sosyal ve siyasi hareketliliğe yol açtığıdır. 